\title{
OUR EXPERIENCE WITH CONTRAST-ENHANCED VOIDING UROSONOGRAPHY
}

\author{
Karla Rubelj, Lea Oletić, Bernardica Valent Morić and Ivana Trutin
}

Department of Pediatrics, Sestre milosrdnice University Hospital Centre, Zagreb, Croatia

\begin{abstract}
SUMMARY - Vesicoureteral reflux (VUR) is one of the most common anomalies of the urinary system in children. Contrast-enhanced voiding urosonography (ceVUS) is one of the best methods in VUR diagnosis. This study compared characteristics associated with VUR specific images and categorized patients according to a particular VUR grade. The study included 183 children. VUR was detected in $38.9 \%$ of patients, mean age $1.7 \pm 1.1$ years. Grade II VUR was most common (60.3\%), followed by grade III (29.4\%). Study results showed that VUR occurred irrespective of age, gender, previous ultrasound findings, causative agent, and severity of urinary tract infection (UTI). VUR was more common in children with recurrent UTI. In the group of children with the first UTI not caused by Escherichia coli or with recurrent UTI, boys more commonly suffered from severe VUR (grade IV-V; $66.7 \%$ ), while girls suffered from moderate VUR (grade II-III; 100\%). In this study, the incidence of VUR in prenatally diagnosed hydronephrosis was $28.6 \%$. It is necessary to develop an algorithm for the treatment of children after UTI in Croatia, which should include ceVUS. All children with possible VUR should be referred to a specialized center where it is possible to perform ceVUS.
\end{abstract}

Key words: Contrast-enhanced voiding urosonography (ceVUS); Vesicoureteral reflux; Children

\section{Introduction}

Vesicoureteral reflux (VUR) is an anatomic and functional abnormality caused by non-physiologic retrograde flow of urine from the bladder into the ureter and renal canal system. VUR is one of the most common anomalies in children and the most common cause of renal scarring in children with a consequence of renal function damage ${ }^{1}$. There is primary and secondary VUR; in primary VUR, the function of the lower urinary tract is normal, whereas secondary VUR is associated with obstruction or impaired function of the lower urinary tract (posterior urethral valve, neurogenic bladder, overactive bladder, urinary disorders after bladder surgery, ureterocele, calculus, etc. $)^{2}$. VUR is associated with renal nephropathy and scarring, which can cause hypertension and renal failure. It is impor-

Correspondence to: Karla Rubelj, Kuzminečka ulica 55, HR-10000

Zagreb, Croatia

E-mail: karla.rubelj@gmail.com

Received December 19, 2019, accepted April 27, 2020 tant to diagnose morphological or functional abnormality of the urinary tract in children with proven urinary tract infection (UTI) as a predisposition for kidney damage ${ }^{1}$. It is recommended to exclude VUR in high-risk patients, i.e. those with hydronephrosis, kidney scarring, atypical UTI, in children with complex conditions (urogenital anomalies, neurogenic bladder, or bowel dysfunction), and those with a positive family history of VUR ${ }^{3,4}$.

During childhood, about $8 \%$ of girls and $2 \%$ of boys have a UTI, and it is estimated that there is underlying VUR in $18 \%-40 \%$ of them ${ }^{5,6}$. It is recommended to exclude VUR in the first febrile UTI in a child from 2 months to 2 years of age in cases of atypical bacteria isolated from urine culture (all except for Escherichia (E.) coli) and pathologic findings of kidney and urinary tract ultrasound ${ }^{6-9}$. Kidney ultrasound has been shown to have neither specificity nor sensitivity for VUR detection ${ }^{10}$.

Diagnosis of VUR is based on 3 methods, i.e. voiding cystourethrography (VCU), radionuclide cystogra- 
ain without VUR (\%) $\quad$ VUR (\%)

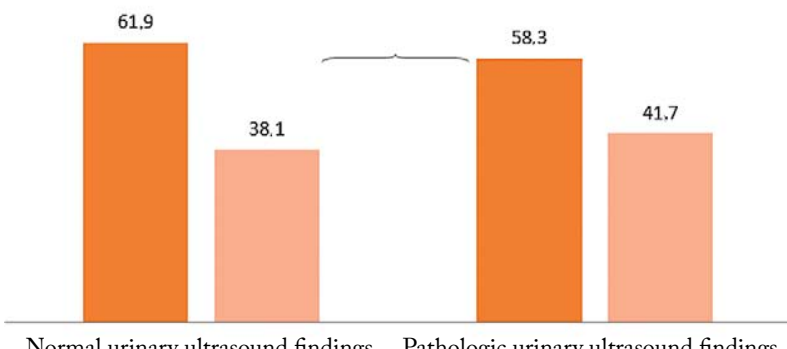

Fig. 1. Comparison of vesicoureteral reflux (VUR) in children with normal urinary ultrasound finding and pathologic urinary ultrasound findings of urinary tract ultrasound.

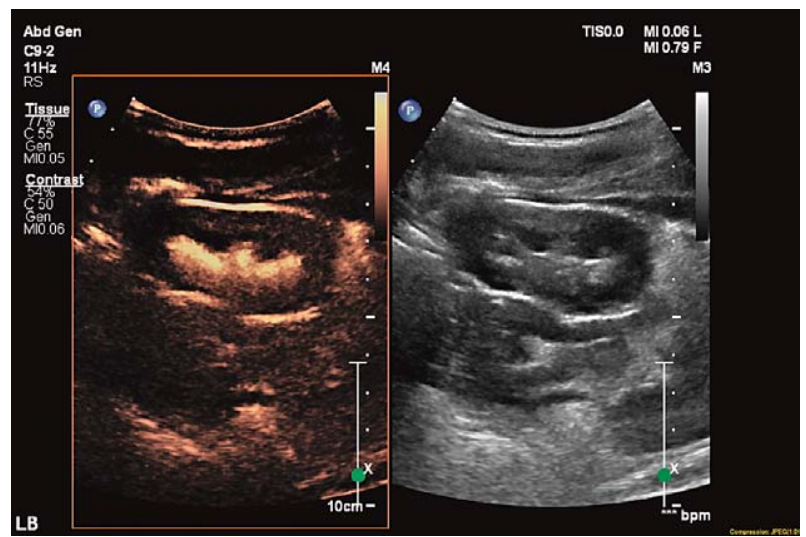

Fig. 2. Grade III-IV vesicoureteral reflux

(active and passive) of the left kidney in a 2-year-old girl with recurrent urinary tract infection.

phy, and contrast-enhanced voiding urosonography (ceVUS) $)^{1,3,11}$.

Today, the sensitivity of ceVUS is very high (ranging from $80 \%$ to $100 \%$ ) with high specificity (ranging from $77 \%$ to $97 \%)^{12,13}$. It has become a routine and professionally recognized method for the diagnosis of VUR in children ${ }^{1,11}$. CeVUS is performed without ionizing radiation, sedation, and use of permanent catheter, it is highly sensitive, affordable, and it provides insight into anatomic details ${ }^{1,14,15}$. The sensitivity of ceVUS is higher than that of micturating cystourethrogram (47\% increase in the detection of VUR was recorded when using ceVUS only $)^{12}$. It is a realtime imaging method that provides continuous extended imaging with a high possibility of detecting VUR as an intermittent phenomenon ${ }^{11}$. According to the recommendations of the European Federation of

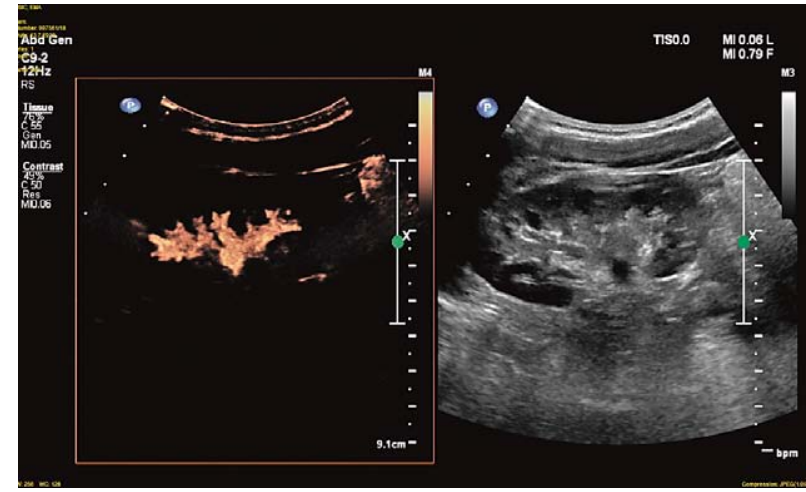

Fig. 3. Grade III-IV vesicoureteral reflux of the left kidney in a 3.5-year-old girl with single umbilical artery syndrome.

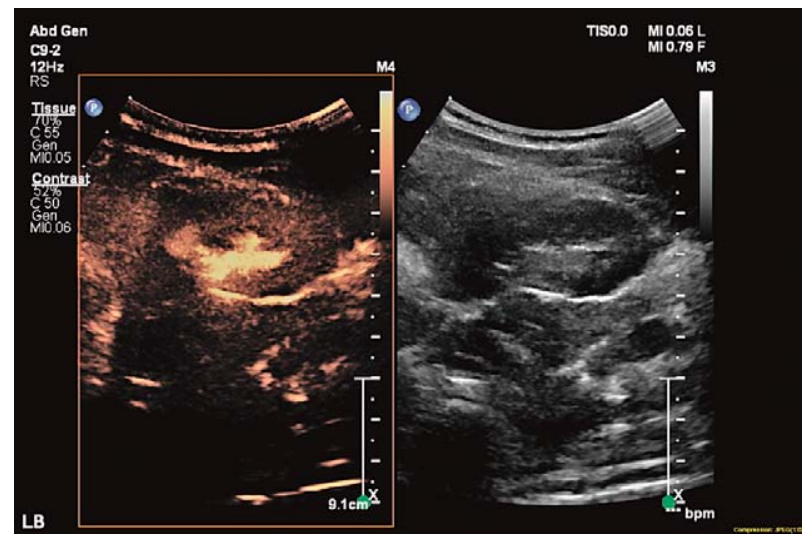

Fig. 4. Grade III-IV vesicoureteral reflux of the left kidney in a 2.5-year-old girl with recurrent urinary tract infection.

Societies for Ultrasound in Medicine and Biology, European Society of Urogenital Radiology, and European Society of Paediatric Radiology, ceVUS is the method of choice in the detection and grading of VUR ${ }^{1}$. The advantage is that, in addition to functional evaluation of the existence of VUR, ceVUS also provides anatomic evaluation of the kidney and bladder via ultrasound $d^{5}$. However, it should be noted that this is a highly subjective procedure, and it depends on the knowledge and experience of the practicing physician ${ }^{16}$. There are certain limitations of the procedure as well, such as possible artifacts due to ultrasound contrast, limited possibility in the examination of fistulas in children with anorectal anomalies or anatomic details of the bladder neck, poor cooperation of the child, or inability to clearly show the kidney due to severe scoliosis. Furthermore, this diagnostic procedure should 
Table 1. Characteristics of all study children

\begin{tabular}{|l|l|l|}
\hline & $\mathrm{n}$ & $\%$ \\
\hline Sex & & \\
Male & 71 & 38.8 \\
Female & 112 & 61.2 \\
\hline Indication for ceVUS & & \\
First UTI & 115 & 62.8 \\
Recurrent UTI & 50 & 27.3 \\
Hydronephrosis & 7 & 3.8 \\
Urogenital anomalies & 6 & 3.3 \\
Neurogenic bladder & 2 & 1.1 \\
Other & 3 & 1.6 \\
\hline ceVUS findings & & \\
Normal & 107 & 61.1 \\
Pathologic & 68 & 38.9 \\
grade I & 2 & 2.9 \\
grade II & 41 & 60.3 \\
grade III & 20 & 29.4 \\
grade IV & 4 & 5.9 \\
grade V & 1 & 1.5 \\
\hline Kidney ultrasound & & \\
Normal & 110 & 60.1 \\
Pathologic & 73 & 39.9 \\
\hline
\end{tabular}

ceVUS = contrast-enhanced voiding urosonography; UTI = urinary tract infection

not be performed during acute infection but after the infection has been treated ${ }^{1,3,11}$.

Determining VUR grade in ceVUS is similar to determining grades in voiding cystourethrography according to the 1985 international system of radiographic grading of vesicoureteric reflux (based on ureteral dilatation and renal duct system). In ceVUS, grading is based on the presence of microbubbles of the ultrasound contrast agent in the ureter and renal duct system, as well as on the grades of dilatation, as follows: grade I - reflux into the distal part of the undilated ureter; grade II - reflux reaches the proximal part of the drainage system without dilatation; grade III - reflux into the dilated ureter and calyces with minimally blunted fornices; grade IV - reflux to the heavily dilated ureter; and grade $\mathrm{V}$ - severe reflux to the gross ureteral dilatation and tortuosity with a loss

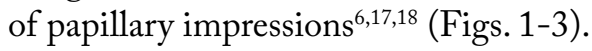

Indications for ceVUS include the first febrile UTI with pathologic findings of urinary tract ultrasound
Table 2. Correlation of VUR with the characteristics in children with UTI

\begin{tabular}{|l|l|l|}
\hline & VUR (\%) & $\mathrm{p}$ \\
\hline Sex & & \\
Male & 37.93 & 0.739 \\
Female & 41.35 & \\
\hline Age (yrs) & & \\
$<1$ & 34.48 & 0.141 \\
$\geq 1$ & 47.06 & \\
\hline Cause & & \\
Escherichia coli & 41.0 & 0.5 \\
Other & 42.0 & \\
\hline UTI & & \\
First & 34.78 & $\mathbf{0 . 0 3 5}$ \\
Recurrent & 53.19 & \\
\hline Urinary tract ultrasound findings & 38.1 & \multirow{2}{*}{0.739} \\
Normal & 41.35 & \\
Pathologic & & \\
\hline Leukocyte count (x10 $/$ L) & 40.28 & 0.7872 \\
$<20$ & 43.75 & \\
$\geq 20$ & 37.5 & 0.46 \\
\hline CRP (mg/L) & 45.45 & \\
$\leq 50$ & & \\
$>50$ & &
\end{tabular}

VUR = vesicoureteral reflux; UTI = urinary tract infection; CRP = C-reactive protein

(e.g., ureterohydronephrosis, scarring, anomalies and malformations of the urinary tract), the first febrile UTI caused by a bacterium other than $E$. coli and first febrile UTI with a positive family history of VUR, recurrent UTI with normal urinary tract ultrasound, prenatal hydronephrosis or other urinary system abnormality, and monitoring of the pre-existing $\mathrm{VUR}^{7}$.

The aim of this study was to examine the indications for ceVUS in children, to determine the correlation of individual characteristics with VUR findings, and to present first results after the introduction of this diagnostic procedure at the Division of Nephrology, Department of Pediatrics, Sestre milosrdnice University Hospital Centre, Zagreb, Croatia.

\section{Materials and Methods}

Data were collected retrogradely from medical records of 183 children scheduled for ceVUS scan at the 
Division of Nephrology, Department of Pediatrics, Sestre milosrdnice University Hospital Centre, from September 2016, when the test was first introduced at the Department, until the end of December 2018.

The test was conducted on a Philips Affiniti $50 \mathrm{G}$ ultrasound machine, with a $2.5-5 \mathrm{MHz}$ convex probe. Sulfur hexafluoride (SonoVue $8 \mu \mathrm{L} / \mathrm{mL}$ ) was used as the ultrasound contrast agent. The ceVUS method detects microbubbles of the ultrasound contrast agent, which are shown in color and on the surface of the ultrasound B-mode images. The precondition is a sterile urine culture and clean urine within 7 days, as well as the informed consent signed by parents. The diagnostic procedure includes initially filling the bladder with the contrast agent (sulfur hexafluoride $(1 \mathrm{~mL}$ SonoVue) was injected into the saline solution). During the filling and discharging phase (spontaneous urination), the bladder and kidneys undergo ultrasound examination via longitudinal and transverse images using contrast-specific software during which the child lies on the abdomen ${ }^{11}$.

Gender distribution, age, ceVUS indications, frequency of pathologic findings on urinary tract ultrasound, and frequency of VUR were analyzed. In children with UTI, we observed gender, age, UTI characteristics (relapse, febrility), distribution of pathogens, inflammatory parameters at the time of infection (leukocytes and $\mathrm{C}$-reactive protein (CRP)), and frequency of pathologic findings on urinary tract ultrasound. We analyzed the correlation of all of the above-mentioned characteristics with the incidence of VUR. CRP values were divided into three groups: low CRP (0-50 mg/L), medium-high CRP (51-100 mg/L) and high CRP ( $>100 \mathrm{mg} / \mathrm{L})$, and leukocyte count into two groups: low leukocyte count $\left(<20 \times 10^{9} / \mathrm{L}\right)$ and high leukocyte count $\left(\geq 20 \times 10^{9} / \mathrm{L}\right)$. According to the ceVUS findings, we divided VUR into groups according to severity, as follows: mild (grade I), moderate (grade II-III) and severe (grade IV-V).

Patient characteristics were expressed as percentage and mean. The $\chi^{2}$-test was used to determine differences between two categorical variables and Student's t-test was used to determine differences between arithmetic means. Values of $\mathrm{p}<0.05$ were considered statistically significant. Approval for the study was granted by the Ethics Committee of the Sestre milosrdnice University Hospital Centre.

\section{Results}

\section{All children}

Contrast-enhanced voiding urosonography was indicated in 183 children, mean age $1.7 \pm 1.1$ years, with a higher prevalence in girls $(\mathrm{n}=112)$ compared to boys $(\mathrm{n}=71) ; \mathrm{M}: \mathrm{F}=61.2 \%: 38.8 \%$. The most common indication for ceVUS in children was the first UTI $(n=115$; $62.8 \%)$, followed by recurrent UTI ( $n=50 ; 27.3 \%)$, perinatal hydronephrosis $(n=7 ; 3.8 \%)$, urogenital tract abnormalities $(n=6 ; 3.3 \%)$, suspected unstable bladder $(\mathrm{n}=2 ; 1.1 \%)$, and other reasons $(\mathrm{n}=3 ; 1.6 \%)$ (Table 1$)$.

Of the total of 183 children having undergone urinary tract ultrasound, 39.9\% (M 28, F 45) had pathologic findings, most often duct system dilatation (90.5\%), more often unilateral than bilateral (61\% vs. $39 \%)$, followed by duplex canal system (4\%), and others $(5.5 \%)$.

Of the total of 183 children indicated for ceVUS, 175 of them underwent the procedure, while the remaining eight did not show up for the procedure on the day it was scheduled. Out of 175 children having undergone ceVUS, VUR was detected in $38.9 \%$ $(\mathrm{n}=68)$, equally in both genders (M 32.3\% vs. F 40.2\%; $\mathrm{p}=0.47$ ). Grade II VUR was most commonly diagnosed (60.3\%), followed by grade III (29.4\%) (Table 1). In children with prenatal hydronephrosis, VUR was diagnosed in $28.6 \%(n=2)$.

\section{Children with UTI}

Of the total number of children with UTI, 90.1\% ( $n=160)$ were referred to ceVUS. The most common indications were the first UTI (62.8\%) and febrile UTI (both first and recurrent) (75.8\%). Girls were significantly more likely to suffer from recurrent UTI (F $34.6 \%$ vs. M 18.97\%; $\mathrm{p}=0.0466$ ). As expected, the most common cause of UTI was E. coli (78.6\%), followed by E.coli ESBL (6.1\%) and Klebsiella pneumoniae (6.1\%), Pseudomonas aeruginosa (1.5\%) and others (7.6\%). There was similar distribution of pathogens regardless of the first or recurrent UTI.

Of the 183 children, CRP value was recorded in $49 \%$ and leukocyte count in $48 \%$. Low CRP value (62\%) and low leukocyte count (81\%) were most commonly found. Medium CRP was recorded in 13\% and high CRP in $37 \%$ of patients, while high leukocyte count was recorded in $19 \%$ of patients. 
Pathologic findings of urinary ultrasound were found in $35.8 \%$ of children with UTI, significantly more frequently in boys (M 65.5\% vs. F 21.15\%; $\mathrm{p}=0.0001$ ) and in children with the first UTI (first UTI 42.61\% vs. recurrent UTI 23.4\%; $\mathrm{p}=0.0308$ ).

In children with UTI, VUR was found in $39.4 \%$ of them, equally in the following categories observed: (a) both genders (M 37.93\% vs. F 41.35\%; $\mathrm{p}=0.739$ ); (b) children with normal and pathologic ultrasound findings (normal ultrasound $38.1 \%$ vs. pathologic ultrasound $41.35 \% ; \mathrm{p}=0.739$ ); (c) children with UTI caused by $E$. coli and children with UTI caused by other pathogens ( $41 \%$ vs. $42 \%$; $\mathrm{p}=0.5$ ); (d) children with low and moderate to high CRP values $37.5 \%$ vs. $45.45 \%$; $\mathrm{p}=0.46$ ); (e) children with low and high leukocyte count (40.28\% vs. $43.75 \%$; $\mathrm{p}=0.787$ ); and (f) children younger and older than 1 year (before $1^{\text {st }}$ year $34.48 \%$ vs. after $1^{\text {st }}$ year $47.06 \%$; $=0.141$ ). VUR was found significantly more frequently in children with recurrent UTI (recurrent 53.19\% vs. first UTI 34.78\%; $\mathrm{p}=0.035$ ) (Table 2).

In the group of children with the first UTI caused by $E$. coli, the incidence of VUR was not associated with ultrasound finding (normal ultrasound 36\% vs. pathologic ultrasound $35.5 \% ; \mathrm{p}=1.00$ ). There was no severe case of VUR in this group; all children suffered from moderate VUR grade regardless of the ultrasound findings. In the group of children with the first UTI not caused by $E$. coli or with recurrent UTI, severe VUR (grade IV-V; 66.7\%) was more common in boys and moderate VUR (grade II-III; 100\%) in girls.

\section{Discussion}

The incidence of VUR after the first febrile UTI is $30 \%-40 \%$, significantly higher than the incidence of VUR in a healthy population, which is $<1 \% 5,6,8,20$. This is consistent with our results, where VUR was found in $34.78 \%$ of children after the first febrile UTI. The overall incidence of VUR in the observed sample was $39.4 \%$, and among them, $41.7 \%$ had pathologic ultrasound findings. The results of this study indicated a similar prevalence of VUR in children with normal ultrasound findings and those with pathologic ultrasound findings during UTI. The above-mentioned leads to a conclusion that ultrasound findings cannot be considered a relevant screening tool for VUR after the first febrile UTI $I^{1,10,21,22}$. Observing the children af- ter the first UTI caused by E. coli, all these patients had moderate VUR (grade II-III), which is not the case with other infectious agents that lead to severe VUR (grade IV-V). These findings are consistent with the current research ${ }^{6}$. The results of this study are in line with the currently applied guidelines issued by the American Academy of Pediatrics and the National Institute for Health and Care Excellence, where no further testing is required in children aged 2-24 months after the first febrile UTI in which $E$. coli has been isolated as a causative agent and in the case of normal ultrasound findings of the kidney and urinary tract $^{6,7,24-26}$. Further testing for VUR is indicated in the case of recurrent UTI, the first UTI with the causative agent other than E. coli, and in pathologic ultrasound findings ${ }^{7,25}$. Somewhat similar results were obtained in this study; VUR was confirmed in $53.19 \%(\mathrm{n}=25)$ after recurrent UTI, which is slightly lower than that reported in the reference works $(70 \%-75 \%)^{10}$. However, other characteristics observed, such as the causative agent of the infection and ultrasound findings, were not significant indicators of VUR in our study, contrary to the above-mentioned guidelines.

In this study, we did not find the severity of UTI to influence the incidence of VUR. Thus, CRP and leukocyte count in UTI alone cannot be considered indicators of VUR. Furthermore, the age of children was not in correlation with VUR incidence in this study. We did not find a statistically significant gender difference in the prevalence of VUR, but we did find that girls had recurrent UTI more often than boys, whereas boys had pathologic ultrasound findings of urinary tract more frequently during UTI. However, these insights do not help us predict the presence of VUR. This study indicated that children with the first UTI caused by $E$. coli suffered from lower grade VUR (100\% had VUR grade I-III vs. $86.1 \%$ of VUR grade I-III in children with recurrent UTI and the first UTI caused by bacteria other than E. coli), which has also been reported elsewhere ${ }^{6,19}$.

Four percent of patients were referred to ceVUS due to prenatal hydronephrosis, which is consistent with other studies. The reported incidence of VUR in prenatally diagnosed hydronephrosis is $17 \%-37 \%$, and in this study, it was $28.6 \%^{7,24}$. The genetic component of multifactorial polygenic or autosomal-dominant VUR inheritance needs to be mentioned as well. In a child with the first febrile UTI whose siblings have 
proven VUR, VUR should be considered due to the $30 \%-60 \%$ incidence of VUR in closest relatives ${ }^{5,6,8}$. It is even recommended to consider VUR in siblings and children of parents with severe $\mathrm{VUR}^{23,27}$.

In studies where VUR was diagnosed using only ceVUS or only VCU, there was a $47 \%$ increase in the detection of VUR when using only ceVUS (ceVUS $56 \%$ vs. VCU 9\%). The exception is suspected pathology of the urethra where the method of choice is still $\mathrm{VCU}^{16}$.

Analyzed data point to a higher likelihood of underlying VUR in recurrent UTI, whereas gender, age, urinary tract ultrasound examination, severity, and other causative agents of UTI have no predictive value for VUR detection. CeVUS is one of the best choices in modern nephrology for detection of VUR, with high sensitivity and negligible side effects. Also, girls suffer from recurrent UTI significantly more often than boys. Every child with indications for VUR should be referred to a center that has experience in ceVUS examination ${ }^{28}$.

\section{References}

1. Roić G, Roić AC, Palčić I, Grmoja T, Batoš AT. Contrast-enhanced voiding urosonography (ceVUS) in the diagnosis of vesicoureteral reflux. Lijec Vjesn. 2016;138:39-46.

2. Gordon I, Barkovics M, Pindoria S, Cole TJ, Woolf AS. Primary vesicoureteric reflux as a predictor of renal damage in children hospitalized with urinary tract infection: a systematic review and meta-analysis. JASN. 2003;14(3):739-44. doi: 10.1097/01.asn.0000053416.93518.63

3. Cvitković Roić A, Roić G, Palčić I, Kekez AJ. Contrast-enhanced voiding urosonography (ceVUS) as a diagnostic tool in evaluation of vesicoureteral reflux. Paediatr Today. 2016;12(1): 56-65. doi: 10.5457/p2005-114.134

4. Spajić B, Đelmiš J, Spajić M, Štimac G, Katušić J, Kraus O. Choice of operative methods for primary vesicoureteral reflux. Acta Clin Croat. 2006;45:187-92.

5. Moradi M, Diamond DA. Summary of recent AUA guidelines for the management of vesicoureteral reflux in children. AFJU. 2013;19:155-9. doi:_org/10.1016/j.afju.2013.06.001

6. Shaikhet N, Ewing AL, Bhatnagar S, Hoberman A. Risk of renal scarring in children with a first urinary tract infection: a systematic review. Pediatrics. 2010;126(6):1084-91. doi: 10.1542/peds.2010-0685

7. Roberts KM, for the Subcommittee on Urinary Tract Infection, Steering Committee on Quality Improvement and Management. Urinary tract infection: clinical practice guideline for the diagnostic and management of the initial UTI in febrile infants and children 2 to 24 months. Pediatrics. 2011;128 (3):595-610. doi: 10.1542/peds.2011-1330

8. Tekgul S, Riedmiller H, Hoebeke P, Kočvara R, Nijman RJM, Radmayer C, Steing R, Dogan HS. EAU guidelines on vesicoureteral reflux in children. Eur Urol. 2012;62:534-2. doi: 10.1016/j.euroro.2012.05.059

9. Jackson EC. Urinary tract infection in children: knowledge updates and a salute to the future. Pediatr Rev. 2015;36(4):153-6. doi: 10.1542/pir.36-4-153

10. Mahant S, Friedman J, MacArthur C. Renal ultrasound findings and vesicoureteral reflux in children hospitalized with urinary tract infection. Arch Dis Child. 2002;86:419-20.

11. Duran C, Beltran VP, Gonzales A, Gomez C, Del Reigo J. Contrast-enhanced voiding urosonography for vesicoureteral reflux diagnosis in children. Radiographics. 2017;37(6):185469. doi: $10.1136 /$ adc.86.6.419

12. Papadopoulou F, Anthopoulou A, Siomou E, Efremidis S, Tsamboulas C, Darge K. Harmonic voiding urosonography with a second-generation contrast agent for the diagnosis of vesicoureteral reflux. Pediatr Radiol. 2009;39:239-44. doi: 10.1007/s00247-008-1080-x

13. Ključevšek D, Battelino N, Tomažič M, Kersnik Levart T. A comparison of echo-enhanced voiding urosonography with $\mathrm{x}$-ray voiding cystourethrography in the first year of life. Acta Paediatr. 2012;101:e235-9. doi: 10.1111/j.1651-2227.2011. 0211.02588.x

14. Tse KS, Wong LS, Lau HY, Fok WS, Chan YH, Tang KW, et al. Paediatric vesicoureteric reflux imaging: where are we? Novel ultrasound-based voiding urosonography. Hong Kong Med J. 2014;20:437-43. doi: 10.12809/hkmj144215

15. O'Hara SM. Vesicoureteral reflux: latest opinion for evaluation in children. Radiology. 2001;221:283-4. doi: 10.1148/radiol.2212011309

16. Chua ME, Kim JK, Mendoza JS, Fernandez N, Ming JM, Marson A, et al. The evaluation of vesicoureteral reflux among children using contrast-enhanced ultrasound: a literature review. J Pediatr Urol. 2019;15:12-7. doi: 10.1016/j.jpurol. 2018.11.006

17. Schlief R, Schuerman R, Neindorf HB. Basic properties and results of clinical trials of ultrasound contrast agent based on galactose. Ann Acad Med Singap. 1993;22(5):762-7.

18. Mardešić D, Barić I, editors. Pedijatrija. Zagreb: Školska knjiga, 2016; p. 893-951. (in Croatian)

19. Riccabona M. Application of a second-generation US contrast agent in infants and children - a European questionnaire-based survey. Pediatr Radiol. 2012;42(12):1471-80. doi: 10.1007/ s00247-012-2472-5

20. Garin EH, Campos A, Homsy Y. Primary vesicoureteral reflux: review of current concepts. Pediatr Nephrol. 1998;12(3):24956. doi: $10.1007 / \mathrm{s} 004670050448$

21. Massanyi EJ, Preece J, Gupta A, et al. Utility of screening ultrasound after first febrile UTI among patients with clinically significant vesicoureteral reflux. Pediatr Urol. 2013;82(4):9059. doi: 10.1016/j.urology.2013.04.026 
22. Blane CE, Dipietro MA, Zerin M, et al. Renal sonography is not a reliable screening examination for vesicoureteral reflux. J Urol. 1993;150:752-5. doi: 10.1016/s0022-5347(17)35605-7

23. Roberts KB. Revised AAP guideline on UTI in febrile infants and young children. Am Fam Physician. 2012;86(10):940-6.

24. National Collaborating Centre for Women's and Children's Health (UK). Urinary Tract Infection in Children: Diagnosis, Treatment and Long-term Management. London: RCOG Press, 2007.

25. Tullus K. Vesicoureteric reflux in children. Lancet. 2015;385 (9965):371-9. doi: 10.1016/S0140-6736(14)60383-4
26. Valent Morić B, Žigman T, Ćuk M,Žaja O, Malenica M. Postnatal evaluation and outcome of infants with antenatal hydronephrosis. Acta Clin Croat. 2011;50:451-5.

27. Peters CA, Skoog SJ, Arant BS Jr, Copp HL, Elder JS, Hudson $\mathrm{RG}$, et al. Summary of the AUA guideline on management of primary vesicoureteral reflux in children. J Urol. 2010;184(3): 1134-44. doi: 10.1016/j.juro.2010.05.065

28. Hrvatsko društvo za pedijatrijsku nefrologiju. Dijagnostički i terapijski postupnik uroinfekcija u djece. Available from: http://www. hdpn.org/datoteke/Dijagnosti\%C4\%8Dki\%20i\%20terapijski\%20 postupnik\%20\%20uroinfekcija\%20u\%20djece.pdf. (in Croatian)

Sažetak

\section{NAŠA ISKUSTVA S ULTRAZVUČNOM KONTRASTNOM CISTOGRAFIJOM}

\section{K. Rubelj, L. Oletic, B. Valent Morić i I. Trutin}

Vezikoureteralni refluks (VUR) je jedna od najčešćih anomalija mokraćnog sustava u dječjoj dobi. Kontrastom pojačana mikcijska cistoureterografija (ceVUS) postaje priznata metoda za dijagnozu VUR-a u specijaliziranim centrima. U našem radu htjeli smo utvrditi indikacije za izvođenje ceVUS-a, provjeriti postoje li karakteristike povezane s VUR-om te time možda moći predvidjeti koja su djeca u većem riziku za VUR. VUR je dokazan u 38,9\% od 183 obrađene djece, srednje dobi $1,7 \pm 1,1$ godina, a najčešće je dijagnosticiran VUR II. stupnja (60,3\%) i III. stupnja (29,4\%). Naši rezultati pokazuju da je pojava VUR-a neovisna o spolu, dobi, prethodnom nalazu ultrazvuka, uzročniku i vrijednostima upalnih parametara kod uroinfekcije, ali je zato statistički značajno povezana s recidivom uroinfekcije. Treba napomenuti da se u skupini djece s prvom uroinfekcijom koja nije uzrokovana bakterijom Escherichia coli ili kod recidiva većinom kod dječaka otkriva VUR visokog stupnja (IV.-V. stupanj u 66,7\% slučajeva), dok djevojčice imaju VUR umjerenog stupnja (II.-III. stupanj u 100\% slučajeva). U našem istraživanju je incidencija VUR-a kod prenatalne hidronefroze bila $28,6 \%$. Nameće se potreba izrade algoritma obrade djece u Hrvatskoj nakon preboljele uroinfekcije i uvrštenje ove nove pretrage u algoritam. Kod sumnje na VUR djecu treba uputiti u specijalizirani centar gdje je moguće raditi ceVUS.

Ključne riječi: Mikcijska cistoureterografija pojačana kontrastom (ceVUS); Vezikoureteralni refluks; Djeca 